This item was submitted to Loughborough's Research Repository by the author.

Items in Figshare are protected by copyright, with all rights reserved, unless otherwise indicated.

\title{
Strangers within? Russian-speakers' migration from Latvia to London: a study in power geometry and intersectionality
}

PLEASE CITE THE PUBLISHED VERSION

https://doi.org/10.1080/1369183X.2016.1249054

\section{PUBLISHER}

Routledge, Taylor and Francis Group (@ Informa UK Limited)

VERSION

AM (Accepted Manuscript)

\section{PUBLISHER STATEMENT}

This work is made available according to the conditions of the Creative Commons Attribution-NonCommercialNoDerivatives 4.0 International (CC BY-NC-ND 4.0) licence. Full details of this licence are available at: https://creativecommons.org/licenses/by-nc-nd/4.0/

\section{LICENCE}

CC BY-NC-ND 4.0

\section{REPOSITORY RECORD}

Lulle, Aija, and Iveta Jurkane-Hobein. 2019. "Strangers Within? Russian-speakers' Migration from Latvia to London: A Study in Power Geometry and Intersectionality”. figshare. https://hdl.handle.net/2134/35596. 


\title{
Strangers within? Russian-speakers' migration from Latvia to London: a study in power geometry and intersectionality
}

\section{Aija Lulle and Iveta Jurkane-Hobein}

\begin{abstract}
This paper seeks to contribute to debates on ethnic identification and migration through a focus on a specific group - Russian-speakers from the Baltic state of Latvia who have migrated to the UK. Twenty-six interviews with members of this group were gathered in London and the wider metropolitan area during 2012 and 2014. Russian-speakers represent uniquely combined configurations of 'the other within': in most cases, they are EU citizens with full rights; yet, some still hold non-citizens' passports of Latvia. While in Latvian politics Russian-speakers are framed as 'others' whose identities are shaped by the influence of Russia, interview findings confirm that they do not display belonging to contemporary Russia. However, London is the 'third space' - a multicultural European metropolis - which provides new opportunities for negotiating ethnic identification. Against the background of triple 'alienation' (from Latvia, from Russia and from the UK) we analyse how ethnicity is narrated intersectionally with other categories such as age and class. The findings show that Russian-speaking migrants from Latvia mobilise their Europeanness and Russianness beyond alienating notions of (ethno)national identity. The paper also demonstrates that being open to ethnicity as a category of practice helps us towards a progressive conceptualisation of often overlooked dimensions of integration of intra-EU linguistic 'others'.
\end{abstract}

Keywords: Intersectionality, Power geometry, Intra-EU mobility, Russian-speakers, Latvia, London 


\section{Introduction}

Ethno-linguistic minorities within the EU are often overlooked groups, in total reaching about $9 \%$ of the total populations of the new EU member states that joined the EU after 2004 (Ivlevs 2013: 43 cf Predan 2004). In the Baltic state Latvia, the ethno-linguistic minority Russian-speakers - makes up about one third of population. Today, Latvia is experiencing large-scale emigration since the country joined the EU in 2004. In this article we study Russianspeaking Latvian migrants in London.

Russian-speaking migrants represent unique spatial and temporal configurations in the post-Soviet space, the Baltic region and the EU. In a 'third space' - like London, which is the research locus in this paper - this group of migrants reveals intersections where ethnic selfidentification and assigned ethnicity provide rich empirical territory. The concept of third space in migration studies are related to postcolonial conditions (Gutiérrez 1999), changing and mixing ethnic identities and races (Bhabha 1994), diversity in metropolis (Soja 1996) and diasporas (Gupta and Ferguson 1997. Power configurations, place and identity processes are particularly relevant in the notion of third space. Soja (1996: 279) linked the abstract notion of the third space to lived reality in a metropolis: as 'a meeting ground, a site of hybridity and mestizaje and moving beyond entrenched boundaries [but] obtains meaning only when practiced and fully lived.'

Our theoretical ambition is to contribute new understanding of the dynamic nature of ethnic identification in different spaces and times. Instead of the ethnic term 'Russian' we use the notion 'Russian speaking', which is not meant as an external categorisation but as subjective account. As Aptekar (2009) states, this is not only a common convention in policy and practice, but also it is more precise because many people come from and continue forming ethnically mixed partnerships. 
Applying the intersectionality approach (McCall 2005) and drawing on 26 in-depth interviews with Russian speakers from Latvia in London and metropolitan area, we analyse how class, family status and dwelling experiences in London contribute to Russian-speakers' subjective identity formation. Notions of intersectionality and power asymmetry will underlie our approach to ethnicity in this paper. We argue that, on the one hand, the Latvian Russianspeakers try to actively change the 'power geometry' (Massey 2005; 2009) from being an unfavourable minority in Latvia to a resourceful agent with desirable language skills and a European passport. On the other hand, however, fully 'ours' or 'svoi/свои' (in Russian) they are in neither of the societies.

\section{Immigration to and emigration from Latvia}

The proportion of Russian-speakers in Baltic states increased due to centrally-planned migration policy of the Soviet Union. During Soviet times, Russian was the official and a common language of communication throughout the Baltic region. However, after the collapse of the USSR, all three countries adopted laws stating that Estonian, Latvian or Lithuanian would be the only state language in these respective countries. The three Baltic states are the only post-Soviet countries which are members of both the EU and NATO since 2004. Currently the Russian-speaking population in Latvia, including many of those who are Latvian citizens is approximately $36 \%$ (CSB Census 2015). It should be taken into account that the Russianspeaking population rapidly decreased after the collapse of the USSR due to the emigration of professional elites and military personnel and their families (Heleniak 2004). But Russianspeaking populations have also decreased due to new labour migration, especially after joining the EU.

Our paper focuses on Russian-speaking emigrants from Latvia, where the proportion of this population is the highest in the three Baltic states. The overall population is rapidly declining 
in Latvia: it was 2.3 million after the country regained its independence in 1991 but due to low birth rates and, most importantly, high emigration, it stood only at 1.9 million at the beginning of 2015 (CSB, Population 2015). According to the Census in 2011, at least 220,000 emigrated from Latvia during 2001-2011. Emigration of Russian speakers is relatively higher when compared with the other ethnic groups living permanently in Latvia. For instance, in 2014, $50.8 \%$ of long-term emigrants from Latvia were Latvians, 30.1\% Russians, $2.4 \%$ Belorussians, and 2.9\% Ukrainians (CBS, IBG041 2015; Jurkane-Hobein 2015). According to econometric calculations, in the UK there could be living around 100,000 people from Latvia (see e.g. Hazans 2011). If we consider data from the Workers Registration Scheme (WRS 2011) 79,754 persons from Latvia registered between May 2004 and April 2011, when the scheme ended. However, these data should be treated with caution because not all stayed in the UK; some engaged in onward migration to other countries or returned to Latvia. According to the Census in England and Wales, (2011), 54,669 persons stated Latvia as their country of birth, while 31,523 of them stated Latvian as their native language. We can therefore assume that about $40 \%$ speak Russian as their native language.

Yet there is a relative paucity of research that focuses on Russian-speaking migrants from the Baltics; the very few exceptions on recent Russian-speaking migrants from the Baltics include research by Aptekar (2009), Woolfson (2009) and, most recently, Ivlevs (2013). All authors draw attention to highly restrictive citizenship and language policies: Woolfson, referring, inter alia, to Hughes (2005), highlighted the discriminatory regime towards Russian speakers in Latvia and Estonia as a push factor to exit the country - see also the response by Muiznieks (2005) attempting to justify language requirements in order to obtain citizenship in Latvia. Woolfson (2009) also cautioned that exit strategies are part and parcel of the neoliberal economic course of Latvia where workers' rights are neglected. Similarly Ivlevs highlighted the same factors in his study on emigration incentives among the Russian-speaking population 
in Latvia and added a third factor - resentment towards the education system in Latvia and requirements to study in Latvian or bilingually in secondary schools. According to the latest emigrant survey, carried out in 2014 and reaching more than 14,000 respondents online, $62 \%$ of Russian speakers said it is not important to know the Latvian language, compared to $28 \%$ Latvians living abroad who also agreed that the Latvian language is not important in their current lives (Kaprans 2015). Ivlevs (2013: 47) found that Russian speakers, especially in the middle-age group (35-54), are more willing to emigrate compared to Latvian speakers. Aptekar, who interviewed actual migrants in Ireland, emphasised that Russian-speaking emigrants from Latvia emigrated more due to socio-economic factors, contrary to those from neighbouring Estonia, who stressed more the disturbing sense of being an ethnic minority in Estonia (Aptekar 2009: 509). ${ }^{i}$ Yet, this pioneering research on recent Baltic Russian migrants in popular destinations revealed little of the complex subjectivities of these migrants or the dynamic role of ethnic identification. 'Russianness', especially when intersecting with gender and inter-ethnic marriage, may imply negative and stigmatising attitudes in various European countries (see e.g. Heyse 2010: 68 in the context of Belgium).

According to the Citizenship Law (1994), Latvian citizenship was granted to inter-war citizens and their descendants. The status of non-citizens of Latvia was introduced under the law on former USSR citizens (1995). Although the position of non-citizens is considered closer to that of citizens than of other foreign nationals or stateless persons (Brands Kehris 2010: 97), non-citizens have no voting rights and face restrictions with regard to a number of professional occupations, mostly in the public sector. Language regulations, regardless of the citizenship status, involve hundreds of professions where a certain level of Latvian language proficiency is required (Regulations 733: 2009). ${ }^{\text {ii }}$ Naturalisation likewise requires a certain level of Latvian language knowledge to pass a naturalisation exam. Since naturalisation was introduced in 1995 , 143,239 people have received Latvian citizenship including 14,391 underage children who 
naturalised together with their parents (OCMA 2015, data for 31 October). Naturalisation rates peaked immediately after Latvia joined the EU but then plummeted around 2007 and continued to decrease year by year down to less than 1,000 naturalised persons in 2014 .

When Latvia joined the EU, non-citizens needed visas to travel to the EU but after 2007 they can travel without visa, yet non-citizens must acquire work permits in other EU countries. Non-citizens do not enjoy the same travelling freedoms as citizens do: while citizens of Latvia can travel to 102 countries without applying for a visa, non-citizens can do so only to 43 countries (MFA, n.d.). For instance, for entering in non-Schengen Ireland and UK, noncitizens have to apply for a visa. A different asymmetry comes into force with respect to Russia: while citizens of Latvia have to apply for a visa for travelling to Russia, non-citizens can travel without visa to Russia.

What the above-mentioned research and specific regulations in Latvia towards nonLatvian speakers imply is that socio-economic inequalities tend to hit the non-Latvian speakers harder and push them to emigrate. During the profound crisis in 2009-2011, a person without much Latvian language knowledge had a competitive disadvantage to keep the job. Ivlevs (2013: 37), referring to Hazans (2005), also pointed out an economic inequality: ethnic Latvians tend to have $10 \%$ higher net earnings in the early 2000 s compared to ethnic minorities. In sum, what we claim we need to continue pursuing, according to this research, first, is not an 'over-ethnicising' emphasis on ethnicity as a difference or an official discourse in legislation, but intersecting categories where more complex subjectivities and inequalities can be grasped. Second, both Aptekar (2009), on Baltic Russian speakers, and Heyse (2010), on Russian women from former USSR countries, carried out their research in cities and both stated that geographical places - both origin and destination - matter to a great extent and should be taken into account in further research. We will now present our conceptual approach to address the 
research question of how ethnicity is narrated intersectionally and through unequal power relations in different spaces and times.

\section{Narrating power and identity dynamics}

We understand ethnicity as a set of dynamic discursive processes of identification and boundary drawing in social situations (Barth 1969; Jenkins 1994; 1997). Following Brubaker and Cooper (2000), we are aware of an often uncritical linking of ethnicity to identity; importantly, ethnicity is created and shaped through practice. Moreover, we treat ethnicity, in the form of the special discursive subject of a 'Russian speaker', as a category of practice where language is particularly important since, in everyday practices, networks are based on language rather than on ethnicity (Laitin 1995). But we are also aware that strategies of instrumental language knowledge, including switching and shifting language choices in different times and places and within different communities, are very fluid. Smyth and Opitz (2013) give numerous examples of Russian language choices and shifts in various former Soviet republics.

'Category of practice', according to Bourdieu (1977), is a social actor's own view of a certain category, contrary to any analytical practice which is defined by a researcher before the analysis. Similarly, Brubaker (2013) insists that the category of practice is self and other identification in ethno-dynamic terms. In our case, Latvian Russianness, and its specific historical linkage to language practice and meanings attached to it, is this category of practice, narrated by our informants in their own words. Furthermore, we conceptualise the discursive subject of a 'Russian-speaking migrant' as an intersectional category (McCall 2005). In other words, it means that we follow how our informants narrate their sense and practice of being a Russian speaker in different spaces and times, such as childhood in Latvia in Soviet times, in post-Soviet Latvia, and after migration to London; but we do not over-ethnicise their 'Russianness'. Both Heyse (2010) and Flemmen (2008) emphasise that ethnic identification is 
a dynamic notion and is importantly influenced by family experiences, especially in transnational marriages. Therefore family status forms one of the most important axes of intersections with ethnicity.

A challenge in the intersectional approach still remains to bring in a class analysis. Here we draw on Skeggs (2004) who emphasises that class processes are inscripted in persons through other categories such as race, gender or ethnicity. Ethnicity, for example, can be used in an exchange process as valuable or might be perceived as having little value in economic or symbolic capital.

However, we still need a conceptual tool to understand how the phenomenon of being a 'Russian-speaker' from Latvia can be better grasped in different times and places. For this reason we incorporate the notion of 'power geometry,' namely, power relations are critically shaped and altered by geography. Doreen Massey (2009) conceptualised power geometry as a dual tool, able to 'capture both the fact that space is imbued with power and the fact that power in its turn has a spatiality’ (Massey 2009: 19). Moreover, as Massey (2005) insists, relational space is always a space in time and therefore co-constructed through socio-political contestation over time. Power geometry helps to highlight inequalities and democracy deficiencies in our sharply uneven world (Massey 2009: 22). In our case, it is creating and recreating unequal power positions and subjectivities of being a 'Russian speaker' in different places.

According to Brubaker and Cooper (2000), ethnicity implies complex negotiations and power relations. Political actors and laws may impose inequalities and limits to pursue certain careers and livelihoods (as we discussed in the cases of language or citizenship requirements in Latvia), and more general historical attitudes can sediment around cultural differences in certain places that can endure in sharp relief over extended time. Therefore we do not treat normative, ascribed terms or procedures such as 'non-citizen' or 'naturalisation' as contextual 
truth 'out there', but we follow closely how informants themselves narrate their experiences and what meanings they attach to them.

Brubaker and Cooper (2000: 26) stressed that the Soviet regime was newly constituting both persons and places as national. In Soviet passports ethnicity was marked, for instance. In everyday life and intergenerationally, it is difficult to distinguish any 'purist' categories of ethnicity, as intermarriage rates are high and language choices are fluid. Through the lens of power geometry and an intersectional approach we therefore also aim to contribute to a critique of over-ethnicisation (see e.g., that introduced by Morosanu 2013: 356-357).

\section{Methodology}

This paper combines life histories collected from two projects. The first group of 11 in-depth interviews were gathered with relatively young people from Latvia who identified themselves as Russian speakers in London in 2012. The remaining 12 interviews were collected in early spring and summer in 2014 . The median age of the sample was 34 , majority were relatively highly skilled, having at least a bachelors' level degree. Their occupations in London varied from casual work in restaurants to freelancing in media, office work and relatively high positions in banks and finance and managing their own businesses. Twelve interviewees had minor children who lived with them. We had slightly more women in the sample, 15 versus 11 men. The length of the interviews was on average between one hour and one hour and a half and the interviewee could choose the language. Four informants chose Latvian or English instead of Russian, while the rest of the interviews were carried out in Russian. Methodologically we see the use of language and switching language preferences as an important element of practice; research participants did identify with several (e.g., Lithuanian, Belorussian), mixed (e.g. half Estonian, half Armenian) and changing ethnicities; but they all claimed that they are Russian speaking. The informants were encouraged to narrate their lives, 
starting from childhood and then moving towards current experiences during migration as well as imaginings on future trajectories.

Two sampling strategies were used to recruit the research participants by the two interviewees both of whom self-identify as ethnic Latvians. In 2012 we developed networks with Russian-speaking informants, starting with two entry points in the leisure-space activities of young Latvians and Russian speakers. In 2014 we experienced difficulties in recruiting interviewees despite using quite extensive recruiting channels for finding appropriate interview candidates including the use of networks of friends and acquaintances, social networks, Facebook groups, and forums for Russians. The timing of the fieldwork during the military conflict in Ukraine could have made work on the question of ethnicity and language more sensitive.

The transcripts were re-read several times, coding intersections of practices and meanings attached to the notion of 'Russian speaker' within a single life story and against other interviews. For most, migration motivations were significantly influenced by socio-economic factors as well as the desire to live outside Latvia. All were citizens of Latvia. Several had taken and passed naturalisation exams with the specific aim to go abroad. The exam was a necessary step to overcome the obstacle for free geographical mobility within the EU. Emerging class notions, family status, and work and dwelling experiences in London critically shape the ensuing analysis. All names are pseudonyms.

In the remainder of the paper, we generally follow the narrative flow in participants' stories, where significant attention was paid to pre-migration histories, current experiences and future imaginations, all closely knit into material and symbolic references to the times and spaces that our informants inhabit (Bailey 2009; Lawson 2000). In the interview analysis, we have strongly relied on the tradition of interpretative symbolic interactionism (Blumer 1959) through the process of abduction suggested by Timmermans and Tavory (2012). Abductive 
analysis encourages synthesis between data, existing concepts and emergence of new concepts. Thus, the analysis process included both inductive and deductive steps enabling the interpretation process being both explorative and grounded in data.

\section{Embracing free intra-EU mobility}

Historically, and especially due to the Soviet system of the movement of people between the Soviet republics, Russian-speaking populations are part of the linguistic landscape in the Baltics. But power relations between the Latvian and Russian languages were reconfigured abruptly after Latvia regained independence in 1991. If Russian was practised as the main language in everyday life, especially in cities, during the Soviet time, despite the fact that both Latvia and Russian were official languages, all this changed after the collapse of the USSR, when only Latvian became an official language in Latvia.

Three main intersections shape the subjectivities of being a Russian speaker vis-à-vis power relations in Latvia and the willingness to leave Latvia in our interview data. First, there was a sense of injustice among the second-generation Russian-speaking migrants, especially in the shift in the compulsory language of schools - Latvian. Second there was a pronounced openness to the opportunities which the free EU movement of people could offer. And third, opportunities elsewhere were a stimulus to overcome the mobility obstacle - to become a Latvian citizen in order to have documents that would allow the person to work and reside freely elsewhere in the EU. Let us look at these intersections more closely.

Typically, those who were descendants of non-Latvians felt in a lower position in the power geometry in newly-independent Latvia. However, this was not simplistically related to language proficiency or citizenship status. No matter how fluent they were in Latvian, the decisive subjective feeling of being less valued was related to their inscription (Skeggs 2004) as 'Russian speakers' and thus not valued members in an ethno-national society. For instance, 
Alona, a high-achieving graduate of the University of Latvia, decided to leave after she received her Master's degree. She comes from a mixed Russian and Belorussian family and describes herself as a Russian speaker although fluent in Latvian, Russian and English.

I never really felt that Latvia wants or needs me. Also, I'm not a Latvian by origin. (..) I feel more free here [in London]. I am a voluntary migrant here, but in Latvia people tend to call me a migrant although I am a second-generation-born Latvian citizen.

Alona's mother and father, whom she barely remembers as her parents divorced early, were 'incomers', as Dzenovska (2012) has vividly described in her ethnography of everyday life in Latvia. Alona's mother was born in Belorussia, but her mobility experience during the Soviet times alone, however, did not create what Ivlevs and King (2012) have named as 'migrating capital'. Alona's moving away from Latvia was crucially shaped by power relations in Latvia where she found that her symbolic linkage to a non-Latvian heritage was devalued. Thus, the negativity of devaluing a 'Russian speaker' as not a full member of society, impacted her sense of freedom in Latvia to achieve professional goals without being inscribed as a perpetual 'incomer.' In order to change the power geometry she needed to move to a different place, where as a Russian speaker she will be differently positioned.

Younger-age informants often stressed that the idea to leave Latvia was internalised already in high school. Taisa, now a graduate from a university in London, recalls her last year in a Russian secondary school in Riga eight years ago:

We were studying foreign languages in my school in-depth. During the secondary school we already had groups aligning according to language preferences: those who studied French were looking towards Paris, those who studied German were willing to 
go to Berlin, and those, like me, who studied English, all wanted to go to the UK or the US. And we all studied Latvian too but nobody was very willing to stay in Latvia. (..) As soon as we passed the naturalisation exams, with my mother we immediately went for an excursion to London. And I liked it, I knew that after a year when I get my secondary school's diploma, I will be gone from Latvia. (..) Almost everyone from my class has left Latvia.

Although young Latvian speakers too have been open to labour migration immediately after the completion of vocational or secondary education (King et al 2016), the openness to the world and to a large metropolis, in particular, seem to be more pronounced amongst the Russian speakers. Clearly, in school systems which are the corner-stones of making future citizens (or ethno-citizens in cases like post-Soviet Latvia). Some young Russian speakers could take an advantage of their native Russian language, since in the bigger EU metropolises there are considerable Russian-speaking communities.

The third intersection, as already introduced in the quote above, was with the citizenship or rather a lack of Latvian citizenship, as the last 'threshold' to be overcome in order to be set free from the unequal power relations in Latvia. Broader power geometry approach also helps to elaborate on what van der Velde and van Naerssen (2011:222) call a 'trajectory threshold' an obstacle somebody should overcome. In our case study, such threshold is a non-citizenship status. A symbolic loop had to be made: to pass a Latvian language test, formally declare loyalty to the state, and thereby obtain Latvian citizenship - in order to move away from Latvia.

I was a non-citizen, although I was born and raised in Latvia but we had these laws (..) I passed the naturalisation exam to leave [Latvia] as it was clear that I would not be 
able to support two children and my mother during the winter time. I had to do something because I could not earn enough money in Latvia (Anastasia).

Like in Anastasia's case, who left during the economic crisis in Latvia in 2009, ${ }^{\text {iii }}$ very rarely did our informants refer explicitly to any discrimination experience. Leaving after Latvia joined the EU or during the crisis was narrated as a general need to improve one's socio-economic situation, regardless of the discursive status of being a Russian speaker and possibly facing formal obstacles to obtain a better job due to lack of Latvian language proficiency. On the contrary, most informants rejected that they themselves have experienced ethnic discrimination and spoke at length about how good their Latvian language knowledge was. This omitting of actual discrimination experiences we interpret as a specific result in an ethno-national and neoliberal country, where a failure to succeed is individualised and stigmatised. Poorer employment prospects and economic conditions due to insufficient language knowledge were more often narrated indirectly, by illustrating such experiences from the lives of friends or relatives, as in a second quote from Alona:

Now I'm sending money to them as my stepfather had two strokes. He has taken early retirement and my mother has trouble finding work as she has trouble with the Latvian language.

In sum, what we infer from accounts of pre-migration experiences is that the status of a Russian speaker in Latvia curbed people's sense of belonging to the independent Latvia, and it was not directly linked to language proficiency as such. It was subjectively felt as a deeper alienating factor, inscribing them as 'strangers' and thus making the decision to leave more 
easy to take and also more pragmatically calculated when encountering socio-economic hardships.

\section{Being a Russian-speaker in London}

When leaving one place and arriving in another, everyday practices, and all that has often been taken for granted, unfold in sharp relief. Language, ethnicity, nationality and migrant status are the key terms of reference used and are further intersected by other categories such as class, age and gender. In the everyday lives of migrants and, possibly even more relevantly, in the lives of migrants who are ethnic minorities in their countries of origin, identities and belonging can be constructed on different scales. If in pre-migration experiences the main juxtaposition was between Latvian (native) speakers and the discursive subject of a 'Russian speaker', the revised power geometry in London is shaped around different axes: Russian-speaking and Latvian-speaking migrants there; Russian-speaking migrants from Latvia and those from other Baltic or post-socialist but now EU countries; and, furthermore, Russian-speaking migrants from Latvia and those from Russia.

\section{Narrating encounters with Latvian speakers in London}

According to those who experienced the collapse of the Soviet Union themselves, the everyday usage of the Russian language was perceived as normal during Soviet times; the rupture was the post-Soviet period when Latvians suddenly 'forgot' Russian and insisted that communication should be held in an 'official' - Latvian - language. These power relations have 'travelled' to some extent also to London. See how Ruslans vividly recalled his encounter with a Latvian man in a bar in London: 
I met a guy from Latvia in a bar and said 'Hello, Maris!' in Russian. But he replied: 'You gonna speak Latvian with me, you understand! Man, you got a Latvian citizenship and thanks to this citizenship you are here in England'. I felt how he started pressuring, pressuring me. But I said: 'Listen, boy! You can reproach me in Latvia if you wish, but we are in a neutral territory now, so let's talk English here'.

Yet, apart from direct encounters, tinged with expectations of conflict as practically and theoretically stressed in various studies on Latvian-Russian language relations back in Latvia (see. e.g. Klave 2011), outside of Latvia differentiation is more strongly related to emerging class hierarchies. There was ubiquitous emphasis in the narratives on how Russian-speaking migrants try to detach themselves from other co-ethnics, not due to language preferences but due to behaviour, class and taste differences. This further helps us to deconstruct the notion of a Russian-speaking migrant 'from within', since migrants not only selectively draw on ethnicity patterns before migration but these inevitably interact with new realities in an immigration place (Boccagni 2014).

However, ethno-linguistic notions enter into yet different power relations in migratory contexts, and even more, in such a large metropolis as London, which are not only nodes of power, wealth and culture but also host millions of foreign-born people (De Genova 2015; Massey 2007; Sassen 1991). Simultaneously, such large metropolises inevitably have the other side of run-down suburbs, disempowerment, poverty and long working hours where migrants rarely can see the wealth and power of the city (Datta 2011; Wills et al. 2010).

Mittelberg and Waters (1992) have identified a three-way dynamics of migrant identity formation. First, an individual immigrant is valued/judged individually. Second, there is the collective or society at large that attaches diverse values and characteristics to all migrants. But these authors propose also a less-known, third type, which they call the 'proximal host', 
namely, the group to which a receiving society may see as related to a recently arrived migrant. The proximal host is the group that the wider society would define as the immigrants' coethnics. As we demonstrated above, the proximal host is already internally diverse in the case of Russian speakers from Latvia, and is furthermore diversified in relations to other migrants.

\section{'Our people' but different from 'Russian Russians'}

The Russian language serves as an important bridging-language, at least among middle-aged migrants from the Baltics and also from some other post-socialist countries. It is not only the instrumentality of the language which plays a decisive role but the sense that 'these people' understand us, 'they are like us', as many informants stressed in cases of positive encounters and when providing mutual support to other migrants of similar socio-economic position. Nashi (Наши, 'ours' - in Russian) was a key word, indicating and symbolising how Russian speakers referred to other Baltic people in London. Anastasia, who worked in a barber shop in a London suburb, first struggled with the English language. However, most of her customers were Baltic or other post-socialist migrants who not only understood Russian but most importantly, could intuitively understand each other even if using some phrases in English.

We keep close friendship with the shop girls from a Lithuanian store nearby. We are on the same street, we are Baltic people, relatives. These shop girls really helped us [to expand the clientele]. They told to all their customers that there would be a barber shop, they said: 'Our people, ours will be working there!' (Anastasia).

The notion of 'our' people helps to increase a sense of relatedness within Russian speakers to some extent, and informants usually spoke rather positively about being perceived as Eastern Europeans - a generalised proximal host in multiple migrant and racial hierarchies in London. 
For those who manage their own business, the use of the Russian language gives them access to clients - through word of mouth, through websites for Russian speakers in UK, and via Facebook groups. The difference from Russian Russians are drawn quote sharply like in Anna's observation. She was working in a bar in a London's neighbourhood where many relatively wealthy Russians from Russia were spending their leisure time.

Do you know how they call us? [Russians from Latvia?] They call us 'Russian speakers! They do not have any interest in history - why we are there, in Baltics, and

why we speak Russian and how comes that my grandmother is from Saint Petersburg. They are full of themselves and we are just some 'Russian speakers (Anna).

In Anna's example we can see how this category of practice works as other identification (Brubaker 2013) and drawing a boundary between a 'Russian Russian' and a 'Russian speaker.' Yet, among Latvian Russians the notion of 'our people' usually embraced post-socialist migrants mainly or even only from outside current Russia itself. We now turn our analysis to how the power axis shifts when examining differences between 'European Russian speakers' and 'pure' Russians from Russia.

\section{European Russian-speaking migrants in London}

Being an EU citizen and a Russian speaker, compared to non-Russian speaking Latvian citizens in London, for some, does turn the power relations in favour of the former, especially the higher skilled. In a metropolis where the economy is based on serving people from many cultures and is interconnected to the world, knowing the Russian language is certainly a plus. Natalia, who went to London due to a new-found romance, explained how she got a job in one of the major luxury department stores in London. 
I got my first job in London easily, thanks to the fact that I am a Russian speaker from Latvia. I did not need any work permit as I am a Latvian citizen and I was also able to have an elegant chat with wealthy Russian customers in their native language.

The importance of London as a residential or tourism base for wealthy Russian visitors or members of the Russian diaspora living in London meant that Russian-speaking staff were key members of this high-end retail store's success.

The 'visibility' of being an Eastern European is an arguable inscription but the language marker - audibility - of hearing somebody speaking Russian is certainly a stronger identifier. Our informants, especially younger ones, rather took a pride highlighting their difference from both Latvians and Russians from Russia.

Actually, I like to emphasise here that I am Russian. I am usually asked whether I am from Poland or from Latvia and how come that I speak Russian. Then I tell the story that Latvia once was a part of the USSR and people usually thank me for being able to tell the story they did not know (Katja).

Like in Katja's words above, also others realised outside their country of birth that they can be proud of being ethno-linguistically different.

Furthermore, despite political discourse and also academic research which warns that Latvia's exclusionary politics towards Russian speakers pushes them to 'turn to Russia' (see e.g. Muiznieks et al. 2013: 294), in the migratory context of London we did not find that Russian-speaking migrants from Latvia would identify with Russia. Let us consider Viktoria's narrative: 
I have always felt myself as a Russian. Always! Even when I was living in Latvia. When somebody asks me here where I am from, I immediately say that 'I am from Latvia but I speak Russian'. (..) I have never said that I am a Latvian. (..) But those Russians who are from Russia are not well regarded here. I saw with my own eyes that scornful expression in the face towards a Russian woman who was really from Russia. There is always the assumption that she just wants to marry an English man to become a British citizen (..) I always emphasise that I am an EU citizen and I had the right to come here (Viktoria).

Note how she arbitrarily emphasises that the 'Russianness' is something she 'always' felt as a part of her identity, and how she further elaborates on the specific ethno-national form of it, precisely as Brubaker and Cooper (2000) noted these complex relations to ethnicity and belonging in post-Soviet space. However, she, like all other our informants, does not turn to identify with Russia as an external homeland. Russia, and Russians from Russia, are ultimately 'others' in the power hierarchy of Russian-speaking migrants in London.

\section{Becoming latvyika outside Latvia}

So what are the future views of Russian speakers who have left their country of birth and experienced how power relations change in different places over time? Firstly, we noted a high level of nostalgia and appreciation of their homeland, Latvia. Like all Latvians, regardless of their ascribed ethnicity, they too expressed nostalgia for Riga, and for the nature (forests, lakes, seaside) and everyday habitus in Latvia. Second, the language of ethno-linguistic 'conflict' that is widely used in political discourses (see analysis of this in e.g. Muiznieks et al, 2013; Klave 2011) in Latvia remains at the level of discursive 'battles' and obscures the reality of how much Russian speakers actually share the same relatedness to Latvia as ethnic Latvians do. ${ }^{\text {iv }}$ Several 
informants stressed that, when being outside Latvia, they started appreciating even more that they are also part of a Latvian culture, they tried listening to Latvian media more through the internet and made some effort to improve their Latvian while in London. A desire to return to Latvia, if economic prospects permit, was pronounced, especially among younger informants. And one of the reasons was that they did not feel fully accepted by English society and tended to be assigned a rather specific socio-economic position in London. Consider the two quotes below:

Let us not forget that England sees itself as the navel of the world. They are the main world centre. Therefore they look at other people from above. They see us as service people (Valerijs).

English people have a completely different culture, sense of humour, values. For example one of the big values for Russians would be classic literature; for an Englishman it would be football. They are less spiritual. (..) With a Latvian or Russian person, if you just met him at the bar, you can sit down, have a couple of drinks and talk openly. English people don't do that. They can discuss football, stuff like that, but the actual private talk, even if you get it, you still feel it's fake. You could say it's a minor concern, but over time it affects you. You start to feel like you are in the wrong place, and that's the feeling that you get constantly in London (Sergei).

Even though these two men, like most of the informants, might well end up by staying in England long-term or for good, they highlighted their awareness that they will always be 'others' in London. But in the meantime, Russian speakers still found themselves in more free and more respected power relations where their mixed ethnicity and linguistic practice were 
not devalued. Jeanne, below, referred to a non-translatable meaning of how she defines herself as a Russian-speaker from Latvia, a latvyika (латвийка - in Russian) in London.

I very much like the term латвийка. Not Latvian, nor Russian, but simply латвийка. I have a very mixed mentality - Latvian Russian mixed mentality, something Eastern European too. (..) My children will be already [a part of] this culture. That's fine but I am just thinking that we will not be a part of their culture. Children will be. I guess, they will feel themselves as English with some roots here.

This 'trans-sectional' identification of Jeanne, and her aspirations for her children, constitutes perhaps one of the most important outcomes from the migration experiences of Russianspeaking migrants from Latvia in London. There are emerging trends of 'becoming' in terms of what most people from the post-soviet Latvia are - mixed ethnicities in shifting power relations. According to Bourdieu (1991: 50-51), symbolic power is making people see and believe what is valuable, but it works only as long as the arbitrary nature of this symbolic power remains unrecognised. The different ethnic and geopolitical power geometry in London helped them to decode their symbolic disempowerment in Latvia and the inscribed quality of a 'Russian speaker', and to experience this, and to capitalise on it, in different space and power configurations.

\section{Conclusion}

In this paper we focused on Russian-speaking migrants from Latvia to London, one of the most attractive destination for the Baltic migrants in past two decades. Our approach was to understand better the subjectivities of Russian-speaking migrants in their own terms. 
We applied the intersectionality approach (McCall 2005) in combination with understanding of unequal power relations as underlying conceptual frame to researching ethnicity and migration. More specifically, followed to how the discursive notion of a 'Russian speaker' and category of practice of speaking Russian is experienced, used, and perceived in different times and spaces. Since power is differently exercised in various places and also material and symbolic meanings, attached to certain processes and people differ, we drew on the notion of 'power geometry' (Massey 2005; 2009) and distinguished the following intersections: embracing free movement of people, being Russian speaker in a metropolis (London) and becoming a Russian-speaking Latvian migrant (Latviyci-in plural) that critically shaped the notion of 'Russian speaking' person.

First, a non-citizen's status for a Russian speaker put him in a weaker power position in both Latvia and also in other EU countries. Therefore it was crucial to overcome the trajectory 'threshold' - to pass the Latvian language and naturalisation laws in order to obtain a 'proper' passport of a Latvian citizen to leave the Latvian state and search for a job or a study place in the EU. People who were born to ethnically mixed or non-Latvian couples, did not relate their own migration incentives to positive attitudes towards migration of their parents as suggested in some research (e.g. Ivlevs and King 2012). There was a certain ease how people narrated a decision to leave Latvia, especially younger people who left immediately after the school but the lasting sense was rather a desire to break away from power positions of being inscribed as a 'Russian speaker' and thus not fully belonging to an ethno-national state. The integration implications therefore are clear, yet hard to implement as they have long sedimented unequal symbolic values attached to native Latvian or a discursive 'Russian speaker.' As long as a Russian speaker feels not a full member of the society with equally valuable cultural and symbolic capitals the incentives to leave will remain relatively strong. For younger informants, 
the idea to leave Latvia was saturating already in schools. They did not relate the future to the Latvian society but to broader European space and opportunities there.

Second, the material and symbolic context of London as a temporary or permanent home to three million or $37 \%$ of the whole metropolis' population, listed as 'foreign born' (de Genova 2015: 4) allowed us to follow the narratives of subjectivities in already different power relations. The practice to position oneself as a Russian speaker is contextual and shifts in interaction with Latvian speakers in London, Baltic or other migrants from mainly postsocialist countries. Command of Russian language also is valued cultural capital in metropolis with connections to the world and businesses, serving Russian-speaking customers.

Third, we found that in migratory context, Russian speakers from Latvia draw a strong boundary between themselves as European (Latvian) citizens and Russian speakers and those from Russia. Being away from Latvia, yet seeing Latvian as a country of birth and a country of citizenship, strengthens the self-identification with the notion of 'Russian speakers from Latvia' (Latvyici).

We reiterate that we treated a 'Russian speaker' as a category of practice being attentive to risks of using pre-constructed, e.g., journalistic and common sense categories (Brubaker 2013). We specifically focused on self- and other identification of migrants as 'Russian speakers'.

These complex intersections where modalities or ethno-linguistic practices reveal themselves, carry both new possibilities and challenges for migrants' integration into immigration places (Boccagni 2014). According to Boccagni (2014:66 cf Pennix et al 2004), the possibilities to integrate better into an immigration place is crucially related to local contexts. In case like presented here, these local-migratory contexts must take into account that migrants come not only from nation states but far more historically complex ethno-linguistic power relations and find themselves in yet other relations in immigration contexts. For instance, 
the positive relation to other Baltic or post-social migrants and emphasis on 'our' people who understand each other can be used as actually existing resource for integration measures beyond nationalistic divisions.

The British EU referendum and consequences of the Brexit are yet unclear and one could only presume that formalising of ties with the UK may be a pragmatic step of our participants. Furthermore, although most of interviewees did not see permanent return to Latvia as a viable option and, especially those, with partners from other ethnicities than Latvian or Russian and raising their children in the British culture, Russian speakers spoke about nostalgia and relatedness to Latvia's built and natural environment (e.g. Riga Old town, houses in Jurmala, Latvian lakes) and habitus they miss when living away from the country of birth. These realities, again, are positive and overlooked resources for return migration and reintegration incentives that currently got wasted by focusing return discourses mainly on Latvians.

We analysed qualitative data and therefore do not claim any representativeness. Further research both qualitative and quantitative on Russian speakers from Latvia and other migrants from ethnic minority groups in different receiving countries can illuminate further what is intersectionality and third space and unequal power relations today in terms of ethnic identity formation during migration.

\section{Acknowledgements}

Lulle received support from the State Research Programme EKOSOC-LV, project No.5.2.4. "Renewal of society through reducing the risk of depopulation, through demographic development and strengthening links with the diaspora for the transformation of the Latvian economy." Jurkane-Hobein carried out the fieldwork during the project "The emigrant communities of Latvia: National identity, transnational relations, and diaspora politics" No. 2013/0055/1DP/1.1.1.2.0/13/APIA/VIAA/040, financed by the European Social Fund and carried out by the Institute of Philosophy and Sociology, University of Latvia. 


\section{References}

Aptekar, S. 2009. Contexts of exit in the migration of Russian-speakers from the Baltic countries to Ireland. Ethnicities, 9(4): 507-526.

Bailey, A.J. 2009. Population geography: lifecourse matters. Progress in Human Geography, $33(3): 1-12$.

Barth, F. 1969. Ethnic groups and boundaries. The social organization of culture difference. Oslo: Universitetsforlaget.

Blumer, H. 1969. Symbolic interactionism. Perspective and method. California: University of California Press.

Bourdieu, P. 1977. Outline of a Theory of Practice. Cambridge: Cambridge University Press.

Bourdieu, P. 1991. Language and Symbolic Power. Cambridge: Polity Press.

Brands Kehris I. 2010. Citizenship, participation and representation. In: Muiznieks N (ed) How Integrated is Latvian Society? An Audit of Achievements, Failures and Challenges. Riga: University of Latvia, Academic Publishing: 93-123.

Brubaker R and Cooper F. 2000. Beyond Identity, Theory and Society 29, 1-47.

Brubaker, R. 2013. Categories of analysis and categories of practice: a note on the study of Muslims in European countries of immigration, Ethnic and Racial Studies 36: 1-8.

Citizenship law (1994). Riga: Parliament of the Republic of Latvia. Available http://likumi.lv/doc.php?id=57512 [Accessed 29/11/15]

CBS, Census. 2015. Available:

http://www.csb.gov.lv/sites/default/files/publikacijas/nr 13 2011gada tautas skaitis anas_rezultati_isuma_12_00_lv.pdf [Accessed 21.01.2016.] 
CSB, Population. 2015. Available: http://www.csb.gov.lv/statistikas-temas/iedzivotajigalvenie-raditaji-30260.html [Accessed 01.12.2015.]

Datta, A. 2011. Translocal geographies of London: belonging and otherness among Polish migrants after 2004. In: Brickell, K. and Datta, A. (eds). Translocal geographies: spaces, places, connections. Farnham, Surrey: Ashgate Publishing: 73-92.

De Genova, N. P. 2015. Border struggles in the migrant metropolis, Nordic Journal of Migration Research. 5 (1): 3-10.

Dzenovska, D. 2013. The Great Departure: Rethinking National(ist) Common Sense, Journal of Ethnic and Migration Studies, 39(2): 201-218

Flemmen, A. B. 2008. Transnational Marriages: Empirical Complexities and Theoretical Challenges. An Exploration of Intersectionality, Nordic Journal of Feminist and Gender Research 16(2): 114-29.

Gupta, A. and Ferguson, J. (1997). 'Culture, power, place: ethnography at the end of an era,' in Gupta, A. and Ferguson, J (eds.) Culture, Power, Place: Explorations in Critical Anthropology, London: Duke University Press, 1-32.

Gutiérrez, D. G. (1999) Migration, Emergent Ethnicity, and the "Third Space": The Shifting Politics of Nationalism in Greater Mexico, The Journal of American History, 86, (2): 481-517.

Hazans, M. 2005. Unemployment and the earnings structure in Latvia, World Bank Policy Research Working Paper No. 3504. Available: http://ssrn.com/abstract=659103 [Accessed 29/11/15].

Heleniak, T. 2004. Migration of the Russian diaspora after the breakup of the Soviet Union. Journal of International Affairs, 57(2): 99-117. 
Heyse, P. 2010. Deconstructing fixed identities: an intersectional analysis of Russian speaking female marriage migrants' self-representations, Journal of Intercultural Studies, 31(1): 65-80.

Hughes J. 2005. 'Exit' in deeply divided societies: regimes of discrimination in Estonia and Latvia and the potential for Russophone migration. Journal of Common Market Studies, 43(4):739-762.

Ivlevs A, King R. 2012. Family migration capital and migration intentions. Journal of Family Economic Issues, 33(1):118-129.

Ivlevs, A. 2013. Minorities on the move? Assessing post-enlargement emigration intentions of Latvia's Russian speaking minority. The Annals of Regional Science: An International Journal of Urban, Regional and Environmental Research and Policy, 51(1): 33-52.

Jenkins, R. 1994. Rethinking ethnicity: identity categorization and power, Ethnic and Racial Studies, 17 (2): 197-223.

Jurkane-Hobein, I. 2015. Krievvalodīgo emigrant bērnu transnacionālās saites ar Latviju.' In Lulle, A. and Kḷave, E. (eds). Radot iespējas attīstībai: diasporas bērni un jaunieši. Rīga: University of Latvia, Academic Publishing: 258-272.

Juzefovics, J. 2013. Television news preferences and a sense of belonging among the Russian speaking minority in post-communist Latvia: the case of Panorama and Wremya. Medialni Studia/Media studies, 2: 174-191.

Kaprans, M. 2015. Lielbritānijā dzīvojošo Latvijas emigrantu attālinātā nacionālisma izpausmes: Kulturālā un politiskā dimensija. Akadēmiskā Dzīve. Rīga: LU Akadēmiskais apgāds: $77-88$.

King, R., Lulle, A., Conti, F. And Mueller, D. 2016. Eurocity London: a qualitative comparison of graduate migration from Germany, Italy and Latvia, Comparative Migration Studies, 4 (3): DOI: 10.1186/s40878-016-0023-1. 
Klave, E. 2011. Language choice and usage in social interaction in Latvia: discourse and practice, Ethnicity studies /Etniskumo Studijos: 42-79.

Laitin, D. 1995. Identity in formation: the Russian-speaking nationality in the post-Soviet diaspora. European Journal of Sociology, 36(2): 281-316.

Law on former USSR citizens. 1995. Full title: Law on the status of those former USSR citizens who do not have the citizenship of Latvia or that of any other state, Riga: Parliament of the Republic of Latvia http://ikumi.lv/doc.php?id=77481 [Accessed 29/11/15]

Lawson, V.A. 2000. Arguments within geographies of movement: the theoretical potential of migrants' stories. Progress in Human Geography, 24 (2): 173-189.

Leetmaa,K.,Tammaru,T. and Baldwin Hess, D. 2015. Preferences Toward Neighbor Ethnicity and Affluence: Evidence from an Inherited Dual Ethnic Context in Post-Soviet Tartu, Estonia, Annals of the Association of American Geographers, 105(1):162-182.

Massey, D. 2007. World city. Cambridge: Polity.

Massey, D. 2005. For space. London: Sage.

Massey, D. 2009. Concepts of space and power in theory and in political practice, Documents d'Anàlisi Geogràfica, 55: 15-26.

McCall, L. 2005. The Complexity of Intersectionality, Signs: Journal of Women in Culture and Society 30(3): 1771-800.

MFA. n.d. Ministry of Foreign Affairs, Republic of Latvia. Al list of countries where Latvian citizens can travel without visas. Available: http://www.mfa.gov.lv/konsularainformacija/celotajiem/arvalstis-dzivojosajiem/valstu-un-teritoriju-saraksts-uzkuram-var-doties-bez-vizas-vai-ieprieks-sanemot-iecelosanas-atlauju

[Accessed 29/11/15].

Mittelberg, D., and Waters, M.C. 1992. The process of ethnogenesis among Haitian and Israeli immigrants in the United States, Ethnic and Racial Studies, 15(3): 412-435. 
Morosanu, L. 2013. Between Fragmented Ties and 'Soul Friendships': The Cross-Border Social Connections of Young Romanians in London, Journal of Ethnic and Migration Studies, 39(3): 353-372.

Muiznieks N. 2005. 'Response to James Hughes. Development and Transitions 2:26-27.

Muižnieks, N., Rozenvalds, J. and I. Birka, I. 2013. Ethnicity and Social Cohesion in the PostSoviet Baltic States, Patterns of Prejudice 47: 288-308.

$\begin{array}{lllll}\text { OCMA. } & 2015 . & \text { Statistics } & \text { on }\end{array}$

http://www.pmlp.gov.lv/lv/sakums/statistika/naturalizacija.html

[Accessed 29/11/15].

Pennix, R., Kraal, K., Martiniello, M., and Vertovec, S. eds. 2004. Citizenship in European cities. Aldershot: Ashgate.

Predan M (ed).2004. Minorities and the Central European initiative: on the occasion of the 10th anniversary of the CEI instrument for the protection of minority rights (1994-2004). Central European Initiative, Executive Secretariat.

Regulations 733. 2009. Regulations Regarding the Amount of the Knowledge of the Official Language and the Procedures for Examination of the Knowledge of the Official Language for the Performance of Professional Duties and Duties of Office, Receipt of the Permanent Residence Permit and Obtaining of the Status of a Long-term Resident of the European Union and the State Fee for Examination of the Fluency in the Official Language Available: http://likumi.lv/doc.php?id=194735\#position=1169_[Accessed 26/05/16]

Sassen, S 1991. The global city: New York, London, Tokyo, Princeton University Press, Princeton, NJ.

Skeggs, B. 2004. Class, Self, Culture. London: Routledge. 
Smyth, S. and Opitz, C. (eds). 2013. Negotiating linguistic, cultural and social identities in the post-Soviet world. Bern and New York, Peter Lang.

Soja, E. W. 1996. Thirdspace: Journeys to Los Angeles and other Real-and-Imagined Places Oxford: Basil Blacwell.

Timmermans, S., \& Tavory, I. (2012). Theory construction in qualitative research: From grounded theory to abductive analysis. Sociological Theory, 30 (3), 167-186.

van der Velde M and T van Naerssen. 2011. People, Borders, Trajectories: An Approach of Immobility and Future Cross Border Labour Migration in and to the European Union. Area. vol. 43(2): 218- 224.

Wills, J., Datta, K., Evans, Y., Herbert, J. May, J. and McIlwaine, C. 2010. Global cities at work: New migrant divisions of labour. Pluto: London.

Woolfson, C. 2009. Labour migration, neoliberalism and ethnopolitics in the new Europe: the case of Latvia. Antipode: A Journal of Radical Geography, 41(3): 952-982.

WRS. 2011. Workers Registration scheme, HM Revenue and Customs. Available: http://www.hmrc.gov.uk/manuals/ccmmanual/ccm20110.htm [Accessed 29/11/15]

\footnotetext{
${ }^{\mathrm{i}}$ In a recent study on neighbourhood preferences in the Estonian town of Tartu, Leetmaa et al. (2015) analysed data from the 1990s up to the end of 2000s. They found that socioeconomic inequalities, and not ethnic intolerance, are the most crucial factor, while ethnic segregation continues to exist in the town. These findings in a neighbouring Baltic country strengthen our claim to place ethnicity into a broader complexity of intersections also after migration to London.

ii National Centre for Education of Republic of Latvia http://visc.gov.lv/valval/limeni.shtml Three levels A-C with two stages in each level.

iii Latvia experienced sudden and deep economic and financial crisis in 2009-2011, and was forced to ask a loan from the International Monetary Fund and the European Commission to maintain the state budgetary functions.
} 
iv Also, back in Latvia, as Juzefovics (2011: 188) has demonstrated in media studies, ethnodivision lines are more politically heated than real. Even though news media preferences do divide people in Latvia along linguistic lines, there is no evidence of two separate information spaces and a 'threat' to national integration. Russian speakers are interested in news, especially socio-economic developments, to the same extent as Latvian speakers are. 